\title{
Towards a conceptual understanding of dispossession - Belo Monte and the precarization of the riverine people
}

\section{Para uma conceptualização da despossessão - Belo Monte e a precarização da população ribeirinha}

Sören Weißermel - Ph.D. in Geography, postdoctoral researcher and lecturer at the Department of Geography, Urban and Population Geography working group, Kiel University (Germany). E-mail: weissermel@geographie.uni-kiel.de

\begin{abstract}
The construction of the hydroelectric power plant Belo Monte in the Brazilian Amazon displaced thousands of families and caused complex impacts for the affected population. This paper argues that previous studies about dispossession in development contexts have considered both material and immaterial consequences but have not brought these dimensions into a conceptual context. In order to contribute to a deeper analytical knowledge of the mechanisms and multi-level effects of dispossession processes, the paper introduces a perspective on dispossession that focuses on its embeddedness in the symbolic order, its epistemic and ontological dimensions and its psychosocial consequences. Using the example of the affected riverine people, this paper shows that the politics of non-recognition used by the construction consortium caused a process of precarization. This comprised the epistemological dimension, and in turn led to a process of deterritorialization, heavily affecting the riverine people on a psychosocial level.
\end{abstract}

\section{Keywords}

Dispossession. Precarization. Territory. Epistemology. Riverine People. Belo Monte dam.

\section{Resumo}

A implantação da usina hidrelétrica de Belo Monte na Amazônia brasileira deslocou milhares de famílias e causou impactos complexos para a população atingida. Este artigo argumenta que estudos anteriores sobre despossessão em contextos da instalação de projetos de desenvolvimento consideraram tanto as consequências materiais quanto imateriais, porém não trouxeram essas dimensões para um contexto conceitual. A fim de contribuir para um conhecimento analítico mais profundo dos mecanismos e efeitos multidimensionais dos processos de despossessão, o artigo introduz uma perspectiva sobre a despossessão que se concentra em sua inserção na ordem simbólica, em sua dimensão epistêmica e ontológica e em suas consequências psicossociais. Usando o exemplo da população ribeirinha atingida, este artigo mostra que uma política de nãoreconhecimento do consórcio construtor causou um processo de precarização que compreendeu a dimensão epistemológica, levou a um processo de desterritorialização e afetou fortemente os ribeirinhos na dimensão psicossocial.

\section{Palavra-chave}

Despossessão. Precarização. Território. Epistemologia. População Ribeirinha. UHE Belo Monte. 


\section{INTRODUCTION}

On the outskirts of the city of Altamira, a group of riverine people collectively constructed a new neighborhood, which some of them designated the "neighborhood of ghosts". Altamira is located in the Brazilian Amazon, at the Xingu River and close to the newly constructed hydroelectric power plant Belo Monte. The group consisted of some of the approximately 40,000 people who were dispossessed of their land and houses in the lowlands of Altamira (baixão), an area that was to be flooded by the dam's main reservoir. This part of Altamira was located directly at the Xingu River, with two main ports. Regularly, riverine people, who made up a large part of the lowland resident population, left for or returned from their rural dwellings and fishing points on the river's numerous islands. When the construction of Belo Monte advanced, the construction consortium Norte Energia forced these people to leave both their rural and their urban dwellings. Their dual housing model was not recognized. Instead, compensation comprised either a rural or an urban resettlement, both located far away from the river shore; or financial compensation that only allowed them to purchase land at the urban periphery due to Altamira's expensive land market. For a long time, the riverine couple Naldo and Maria refused to leave their land on an island under these conditions. When in August 2015 they received the definite order to leave and went to their island to collect their things, they were shocked by the sight of the burnt remains of their house, their belongings and the nearby plants. A couple of weeks later, Maria expressed her feelings: "That was my paradise. [...] They destroyed me. Never again will I be the same person" (Int_30.09.15 ${ }^{1}$. In the neighborhood of ghosts, this couple and other inhabitants designated themselves as "living deads". Throwing a riverine off the island, ending the fishing and moving him or her to a city with no connection to the river would be synonymous with killing him or her. He or she would not know how to survive without the river and without agriculture.

In contrast to the indigenous population, the riverine population has never been recognized as a distinct social group. In the basic environmental contract of the Belo Monte Project (Plano Básico Ambiental-PBA), which was negotiated between the consortium Norte Energia, the licenser Ibama (Brazilian Institute of Environment and Renewable Natural Resources) and FUNAI (National Indian Foundation), neither the riverine housing model nor their existence as a distinct group was mentioned. The riverine families not only experienced the

\footnotetext{
In this paper, empirical sources are coded by type (Int=interview, GC=group conversation, $\mathrm{T}=$ tour, $\mathrm{Inf}=$ informal talk, $\mathrm{PO}=$ participatory observation) and date.
} 
destruction of their complex community structures. Dispossession brought their fishery to an end, either because of the location of the new settlements or due to the deterioration of water quality because of construction work and damming. Many of the affected riverine people experienced a process of precarization with severe psychosocial consequences.

These findings indicate the complexity of dispossession, reaching beyond material dimensions and encompassing the social and psychological level. This paper argues that previous studies about dispossession in development contexts have opened up different dimensions of dispossession and provided important insights but they have not brought these dimensions into a conceptual context. This suggests the need for a complex perspective on dispossession that allows analytical knowledge of the possible short-, medium-and long-term consequences of dispossession and resettlement. Such knowledge is indispensable not only for critical research but also for practical work in, for instance, development projects that officially foresee the reproduction of destructured ways of life after resettlement. The paper takes a relational theoretical perspective on dispossession, recognition and precarization that focuses on the psychosocial consequences of dispossession, and uses empirical data from field studies in Altamira and the Xingu region. The aim is to contribute to a conceptualization of the concept of dispossession and thus to enable deeper analytical knowledge of the mechanisms and multi-level effects of dispossession processes.

To this end, the following theoretical section introduces a perspective on dispossession that focuses on its embeddedness in the symbolic order, its epistemic and ontological dimensions, and its psychosocial consequences. After portraying the context of the Belo Monte project and its process of displacement and resettlement, I then apply this perspective to two exemplary narratives of riverine people affected by dispossession.

\section{PSYCHOSOCIAL AND EPISTEMIC DIMENSIONS OF DISPOSSESSION}

The impact of large-scale development projects and resettlement programs has been studied in detail since the 1950s. These studies came to be known as DIDR-studies (development-induced displacement and resettlement). They have given a good impression of the risks and consequences of dispossession, developed best-practice models for resettlement (cf. CERNEA; GUGGENHEIM, 1993; CERNEA, 1997) and dealt with the so-called "politics of dispossession" (SAID, 1995) - that is, the political and economic forces behind 
these projects and the goals, strategies and actor constellations of resistance to dispossession (cf. OLIVER-SMITH, 2001, 2009; LEVIEN, 2012; BORRAS; FRANCO, 2013). The notion of dispossession, however, has not been further conceptualized in these studies.

Harvey's (2003) vividly discussed concept of accumulation by dispossession (ABD) has found considerable resonance in studies of capitalist development projects. ABD treats dispossession analytically with regard to its embedding in macroeconomic processes. Dispossession refers particularly to the material level, but remains very abstract overall. The approach of accumulation by extra-economic means takes up this concepts and transfers the concept of dispossession to concrete constellations of power and interests. In contrast to Harvey's economic perspective, Levien (2012) describes ABD as a primarily political process that is only made possible by the concrete intervention of state actors. Hall (2013) supports the relevance of this change of perspective with his reference to forms of disregard and fraud on the part of state or private actors, as are common in large-scale projects, and to unequal structures of legal support that permit these processes. According to these and other analyses from the field of DIDR literature, dispossession not only refers to material factors but also to forms of non-recognition and deprivation of rights. However, these approaches cannot explain how dispossession is concretely effected and how material and immaterial dimensions interact. They indicate the psychosocial dimension of dispossession but do not offer a foundation for its analysis and contextualization. Therefore, theoretical approaches are needed that go beyond structuralist considerations and are able to provide an appropriate analytical foundation.

One approach that seems fruitful in this sense is the dual concept of dispossession of Butler and Athansiou (2013). This concept accepts Hegel's ([1807] 1987, [1820] 2015) close connection between ownership, appropriation and the principle of mutual recognition but fundamentally questions the Hegelian idea of a sovereign subject standing at the end of a dialectical struggle for recognition. Rather, the subject's existential need for social recognition results in its persistent dependence on structures of alterity and submission to intelligible norms. Butler and Athanasiou designate this impossibility of sovereignty and self-ownership as the basic condition of "being dispossessed" (ibid., p. 5). This condition or the first "valence" of dispossession is fundamental for the second valence, that is, the subject's experience of "becoming dispossessed" (ibid.). The dependent relationship automatically harbors the danger that those who are to preserve the subject deprive her or him of elementary things such as livelihood, housing, rights and citizenship. Following this understanding, the actual 
dispossession takes place in the psychosocial consequences of, for instance, the deprivation of the validity of one's own way of life and reality.

The limits of intelligibility that characterize both the normal and the abnormal and thus mark the publicly recognized, normal way of life, simultaneously cause the "marginalization and de-realization of other forms of life" (MEISSNER, 2012, p. 28) ${ }^{2}$. In this regard, Butler and Athanasiou (2013) and Butler (2009) describe as precarious population groups that are outside legal and/or societal recognition and are disproportionately affected by these processes and mechanisms. They are excluded from the public by the intelligible norms: "Precarious life characterizes such lives who do not qualify as recognizable, readable, or grievable" (ibid., p. xii-xiii).With the designation of dispossession as an instrument of control and appropriation, the authors draw orientation from Derrida's concept of ontopology, which describes the binding of a being to a predetermined place or territory. Dispossession works in this context as a regulating practice to put subjects in their "proper place": "the only spatial condition of being that they can possibly occupy, namely one of perennial occupation as non-being and non-having" (BUTLER; ATHANASIOU, 2013, p. 19). Through a process of precarization, people are excluded from the public sphere and their possibility of social and political participation.

In this discussion about the precarization and exclusion of certain groups, Butler and Athanaisou (2013) and Butler (2009, 2011, 2015) refer to Arendt's (1998, 2006) thoughts on the public sphere, in which people, their perspectives and ideas can appear and be seen and heard. In public, structures of meaning are negotiated and sense and reality are constructed. This public sphere, or "space of appearance" (ARENDT, 1998, p. 199), is precisely produced through the political interaction of citizens who come together and debate over different perceptions or interests and thus try to maintain or gain recognition and influence (ibid., p. 199-200). In contrast to Arendt, however, Butler (2011) focuses on politics that try to regulate the public sphere by banning the private out of the public, disguising social inequality within the public sphere and depoliticizing and derealizing the precarious. In this context, the destruction of the private realm is a key factor that impedes people from creating spaces of appearance and being heard and seen in public (cf. ARENDT, 1998).

In the context of development projects in the Global South, such processes of dispossession, non-recognition and precarization have a strong post- or neocolonial context. Santos (2014) identifies the origins of underlying structural forms of paternalism and unequal power of interpretation in a dominant Western

2 All non-English sources have been translated by the author. 
epistemology, whose concepts, theories and inherent dichotomous structures do not recognize alternative perceptions or do not value them as valid contributions. This epistemology originated in the modern, Western, Christian world and was able to establish itself as universal in the guise of modern sciences and their institutionalization on a global level. Thus, an epistemic, hierarchizing order of forms of knowledge and life emerged, which according to Escobar (1992, p. 21) was reproduced and consolidated by the "hegemonic epistemological space" of the development discourse. This discourse is underpinned by Western and capitalist understandings of property, housing and quality of life, among others. In conflicts over displacement and resettlement, these understandings often collide with alternative conceptions (cf. CORRÊA, 2016). Frequently characterized by patronizing politics that try to enforce dominant understandings, such conflicts take on an ontological and epistemological dimension. According to Chaui (2012), in Brazil this happens within an already strongly hierarchized society, which is dominated by clientelism that has established the state as a guarantor of protection in return for political allegiance. Those without a strong link to the state or local authorities and with divergent perceptions like, for instance, certain subaltern groups are frequently inferiorized and affected by a repressive use of the law.

In order to fully capture the effects of such a state-society relation and the inherent use of law, we need to recognize that ontological and epistemological conflicts in the context of dispossession are not only about the material but also significantly about the symbolic appropriation of a certain space or territory. In Brazil, the concepts of territory and territoriality are important conceptual terms in social sciences and they open up a differentiated perspective on the contested production and domination of space. Following Haesbaert (2004), territoriality means the ability to exercise control and influence over a territory. This not only refers to materialities but also to interpretational sovereignty over space and to social and symbolic positioning and movement within space (cf. KATZ; OLIVEIRA, 2016). This understanding of territory and territorialities contradicts the dichotomization of nature and humans. It corresponds to the idea of a hybrid space, which Haesbaert (2004, p. 79) discovers in the complex spatiotemporal relations "between society and nature, between politics, economy and culture and between materiality and 'ideality".

A relational perspective on dispossession, recognition and precarization sets an important focus on the psychosocial effects of the deprivation of recognition within conflicts over dispossession. It underlines the ontological and epistemological dimension and situates events and processes of dispossession within broader struggles about cultural norms of intelligibility and consequent 
historic patterns of recognition and power structures. Thus, this perspective is able to take into account post- or neocolonial contexts that often play a crucial role in development projects. Adding the aspect of territory and territorialization to these considerations importantly complements the thoughts on spatialities found in Butler and Athanasiou (2013) and Butler (2009, 2011, 2015) regarding, for instance, the "proper place" or the private and public sphere. Indeed, the concept of territory can meaningfully capture the complexity of sociospatial relationships and ownership structures as well as the consequences of their loss.

\section{METHODOLOGY}

This paper is based on a $\mathrm{PhD}$ project that included qualitative field research with several stays in Altamira and the Xingu region in the years 2013 to 2018. One central objective of the field research was to understand the situation of the people affected by the construction of the Belo Monte power plant, to give them a voice and space to express their perspectives and stories. However, the constellation of a white, male researcher from a European university researching about subaltern people in the Global South potentially entails asymmetric power relations. Therefore, the empirical methodology needed to use participatory elements to prevent an exploitative structure (cf. HOWITT; STEVENS, 2005). Participative, ethnographic methodology was chosen that focused on living onsite, getting to know the affected people and being immersed in their everyday life, creating relationships and, hence, identifying life-world contexts and processes of meaning construction. Besides sharing everyday activities, this included qualitative interviews and group discussions with a high proportion of narrative sequences, informal talks and tours in the affected and the new neighborhoods accompanied by inhabitants. Furthermore, I participated in political events, including reunions of local social movements, NGOs and grassroots groups, public audiences and meetings between public and private actors and affected people. Participation varied between a mere presence and active involvement in the meetings and political work of social movements and grassroots groups.

\section{THE BELO MONTE PROJECT AND ITS COMPENSATION SCHEME}

With a maximum capacity of 11,233 MW, Belo Monte will be the world's fourth-largest hydroelectric power plant (SIFFERT et al., 2014, p. 120). However, due to strong seasonal fluctuations in the water level the annual average output 
will only amount to 4,571 MW (NORTE ENERGIA, 2019). The reservoir of 478 square kilometers (ibid.) affects numerous riverine families with residences on river islands and shore zones (cf. fig. 1). It also affects twelve districts of Altamira in the spheres of influence of the three tributaries Igarapé Ambé, Igarapé Altamira - which made up most of the urban lowlands called baixãoand Igarapé Panelas (cf. MAB, 2015, p. 109-110; fig. 2). In total, the number of affected people amounts to approximately $40,000^{3}$.

Figure 1 - The Belo Monte power plant complex. The river is dammed by the main dam (Pimental) and redirected via artificial channels to the Belo Monte power plant. The main reservoir covers hundreds of islands formerly inhabited by riverine families

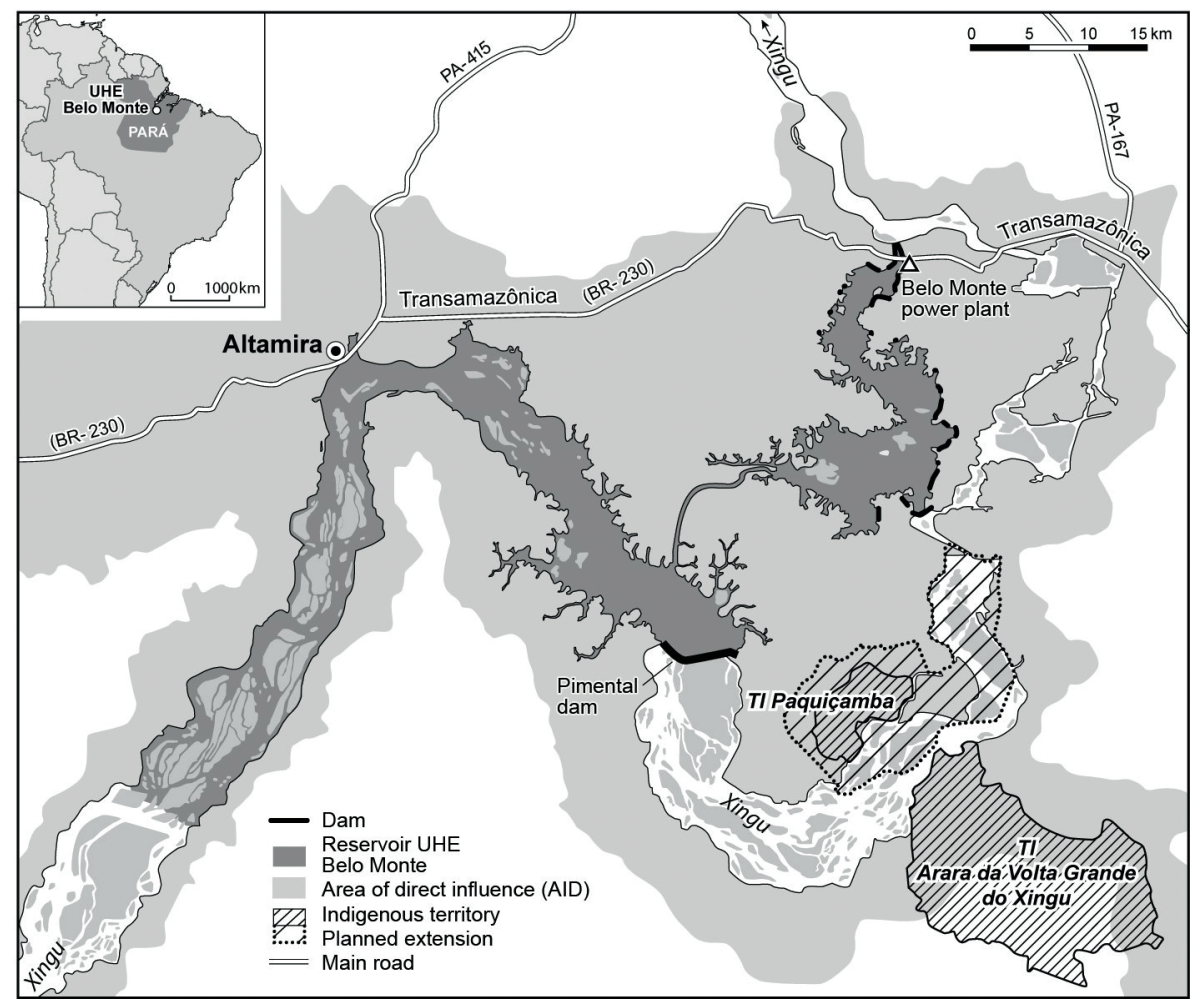

Source: own elaboration based on ISA (2013, p. 46-47).

The official figures from Norte Energia, based on their own registrations, show 30,813 people affected in the urban area (MAB, 2015, p. 110) and 7,750 in the countryside (Palmquist, 2015, p. 123). However, the social movement Movimento dos Atingidos por Barragens (MAB) estimates the number in urban areas alone at around 40,000 (MAB, 2015, p. 110). 
Figure 2 - Altamira before the beginning of the resettlements and the urban sectors of the "directly affected urban area"

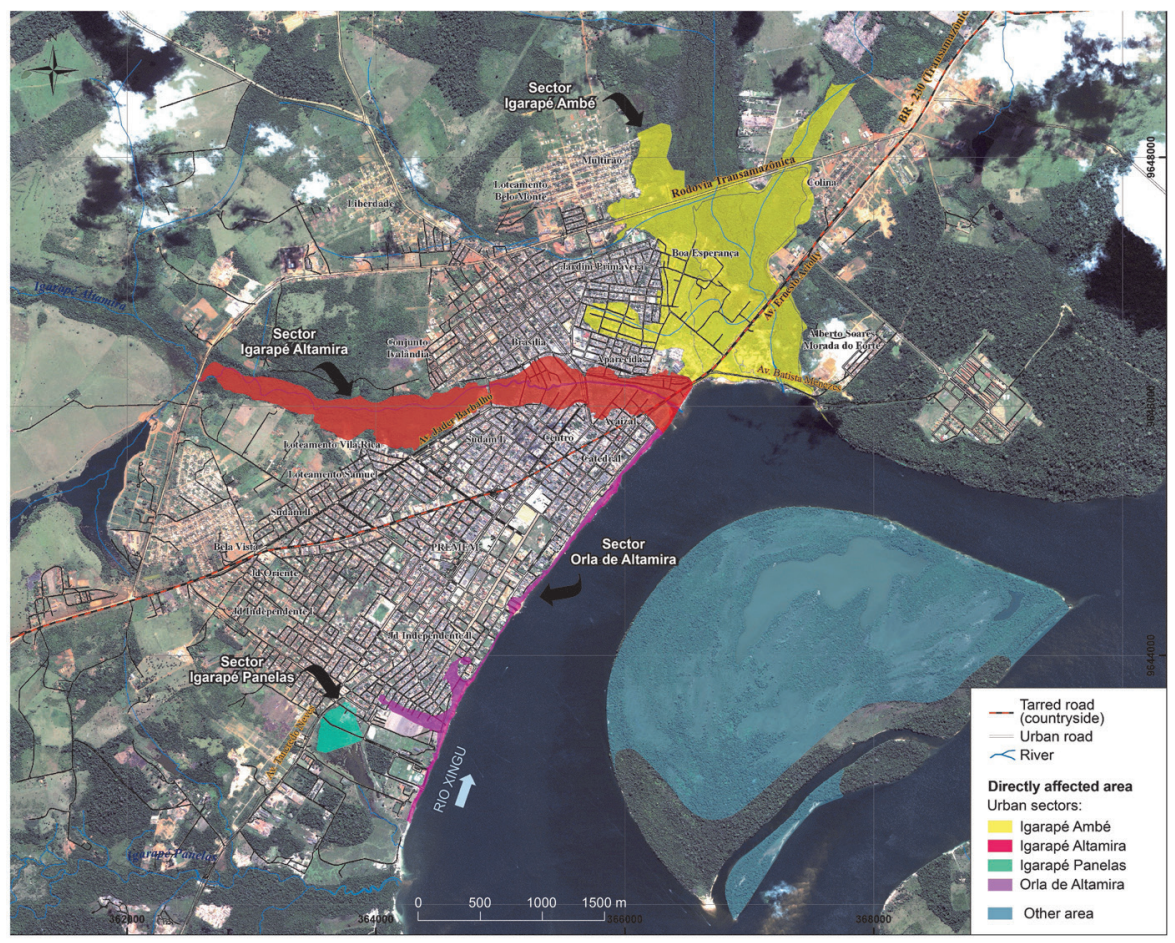

Source: own elaboration based on ELETROBRÁS (2009, p. 21).

The basic environmental contract of the Belo Monte Project (Plano Básico Ambiental-PBA) foresaw three forms of compensation for dispossessed properties: 1. financial compensation according to market prices, 2. assisted relocation (i.e., financial compensation bound to new property), 3. resettlement to one of the newly constructed urban (Reassentamento Urbano Coletivo - RUC) or rural (Reassentamento Rural Coletivo - RRC) settlements. This was preceded by a process of socio-economic registration of families in the directly affected areas. The registration included an assessment determining whether each family was entitled to a house in an RUC or RRC and an estimate of the financial value of the property on the basis of a price book ${ }^{4}$. The financial value of the property depended on its categorization into periphery or center. However, vague criteria categorized only the commercial city center as center, ignoring the centrality of

$4 \quad$ The price book was created by Norte Energia in 2012 and, despite price increases in Altamira and the surrounding area due to strong immigration, has not been revised since then (cf. PO_12.11.14; Int_05.03.15; Nóbrega, 2015, p. 104). Residents were not involved in the creation of the price book, and it was not accessible to all after its creation (cf. PO_12.11.14; Int_09.10.14). 
most quarters of the baixão to the riverbank, ports and the city center, as well as the importance of this centrality for inhabitants (e.g. Int_09.10.14, Inf_21.01.15, Int_05.03.15, GC_14.03.15). A second category divided building materials into masonry - with higher financial value - and other material.

In the case of the wooden stilt houses - the palafitas - these two categories resulted in a further reduction of the already low compensation level based on the outdated price book. This resulted in compensation values of 20,000 to 30,000 Reais, which was not even sufficient for the purchase of a plot of land in Altamira. This increased the demand for the option of resettlement in one of the five RUCs built in Altamira (PO_12.11.14, Int_05.03.15). However, many families were denied the right to a house 5 . Furthermore, ignoring the complex community structures and PBA agreements, families were resettled individually in a dispersed fashion to different RUCs (cf. WEISSERMEL, 2015).

The PBA as well as Norte Energia followed a hegemonic housing model with only one permanent residence either in the countryside or in the city. A Western-centric binary separation of the rural and urban was thus imported into a region where urban and rural life forms were historically interdependent. The dual housing model of the riverine population was a product of this interdependence. Its non-recognition by the PBA and Norte Energia reflected ignorance of its sociocultural and economic importance. Like the majority population, affected riverine people could only choose between either an urban or a rural resettlement. The second house was compensated financially. Options for rural resettlement were located far away from the river in ecologically degraded areas along the Transamazônica or near the Pimental and the Belo Monte dam, where a reproduction of the riverine way of life appeared impossible (cf. Int_14.03.15; Int_ 04.03.15). Therefore, most riverine people decided in favor of the urban option. However, the financial compensation provided for rural dwellings was even lower, as land use here was based on a concession termed TAUS (Termo de Autorização de Uso Sustentáve). The TAUS legally permitted sustainable land use but prevented public land becoming the property of those using it with the usucapião mechanism. For this reason, Norte Energia only compensated the riverine people for building materials and crops. This resulted in low compensation sums of 5,000 to 20,000 Reais (e.g. PO_12.11.14; PO_29.09.15; GC_14.03.15;

\footnotetext{
This concerned cases in which a number of family nuclei lived together in one house and only one nucleus was recognized as the legal owner or when families did not possess the right documents. As these were cases common to the region, they were foreseen in the PBA (Int_05.03.15). However, legal proceedings only became possible when a public defense lawyer arrived in Altamira in January 2015 as a result of public pressure, when displacement and resettlement were already advanced.
} 
Int_14.03.15; Int_08.10.15). Regarding the modification of the river and the impact of this on fishery, the PBA considers consequences on local fish stock but does not translate this into socioeconomic consequences for artisanal fishers (NORTE ENERGIA, 2010, p. 321-338). Artisanal fishery is only mentioned in terms of its allegedly deficient commercialization, which is used to argue that the fishers should be subject to a "project for the promotion of sustainable fishery" (ibid., p. 342-352). For a long time, this patronizing image of the artisanal fishers was exacerbated by Norte Energia ignoring them as relevant actors. It took several fluvial blockades by the fishers' cooperative, the Colonia de Pescadores Z-57, to force their recognition as political actors. In 2014, increased complaints about deteriorating water quality and the depletion of fish stocks due to advanced dam construction led to Norte Energia eventually agreeing to conduct a study in 2015, which, however, neglected any impacts (NORTE ENERGIA, 2015). Based on the PBA, apart from some model projects of aquaculture, the consortium, furthermore, insisted that there would be no compensation of fishery in the period between the river damming and the predicted stabilization of the fish stock five years afterwards (cf. NORTE ENERGIA, 2010, p. 342-352).

The individualist and technical registration and estimation process ignored the importance of community structures in the baixão and in rural settlements at the river shore (beiradão). Here everyday life was built on mutual support, complex local economic integration and joint leisure activities, and this involved an integrated co-existence with the Xingu River and its forest and plants. Using two examples, the following section gives an insight into these structures and the consequences of its displacement-induced disruption.

\section{NARRATIVES OF DISPOSSESSION}

The previous section discussed the process of displacement and resettlement that showed significant inconsistencies regarding the number of registered people, the assignment of a right to compensation and the estimation of the financial values of properties. Furthermore, its technical approach was marked by patterns of non-recognition. This indicates another, fundamental conflict that takes place on an epistemic and ontological level. It is about the prerogative of interpretation over the affected space of Altamira and the Xingu and, hence, about functional and symbolic aspects of territories, spatial claims and territorialities (cf. HAESBAERT, 2005). Following Santos (2014), a Westernoriginated epistemology that determines the functionalist, profit-oriented character of the Belo Monte projects collides with different epistemological and 
ontological perspectives on the relationship between humans and nature, the function of property and social structures, among others (cf. CORRÊA, 2016). This epistemic and ontological dimension of the conflict adds an important analytical perspective to the analysis of the negotiation of meaning structures within the dispossession process, and is particularly evident in the example of the riverine people. Storytelling is an important method for the transfer of knowledge and socialization among these people (cf. GRUPO DE ACOMPANHAMENTO INTERINSTITUCIONAL, 2017, p. 15). Therefore, the following section approaches experiences of dispossession, inherent understandings of property and epistemic foundations by means of two exemplary stories ${ }^{6}$.

\subsection{SÉRGIO AND THE "FISHERMAN WITHOUT A RIVER"}

Sérgio was a community leader in Santo Antônio, a rural riverine settlement that was the first to be displaced for the beginning of construction work. Contrary to previous agreements and the PBA contract, Norte Energia undertook no collective resettlement but dispersedly resettled the residents mainly in the form of assisted relocation. Sérgio got a plot at the Transamazônica, far away from the river and former community and family members, where he had significant problems of adaptation. He saw this displacement to a location that contradicted his needs as representing an invisibilization of the riverine people and a non-recognition of the merit and the cultural importance of artisanal fishery. To confront this invisibilization, together with a student of the Universidade Federal do Pará (UFPA) he produced a documentary about the history of the Santo Antônio community:

I want to tell this story in another way, you know, because sometimes you tell other people about the work as a fisherman in the community and they say: "Well, that's not a big deal". But I show these people in the movie: "Damn, this here is work." Even towards the judiciary, this seems necessary. Once a lawyer said that there were no fishers here at the Xingu (Int_02.03.15).

During a visit to his new house at the Transamazônica (GC_28.02.15) and in a subsequent interview (Int_02.03.15), Sérgio extensively described his former life as a fisherman and riverine in the community and thus gave an impression of the corresponding structures of meaning. Sérgio portrayed the time in Santo Antônio as one of autonomy and freedom. Although it was a simple life, he had everything he needed: "Before, I had my job, I had my hour of leisure, my

\footnotetext{
For reasons of research ethics and confidentiality, the names of the interview partners were changed.
} 
hour of hilarity. I've had my hour to joke, to drink beer. All this didn't demand anything from me. I had the freedom to do so" (Int_02.03.15).

In 14 of his 25 years as a fisherman, Sérgio fished from the boat with a net. During that time, he drove out alone in the late afternoon (Gsp_28.02.15). These moments alone at night on the river meant a lot to him. The river gave him strength and he learned all the songs of birds and other animal sounds. He knew exactly where he could find the different fish species. Since the fish could not be kept fresh, the catch was directly consumed and distributed among the community. When the community began to use money, he started to catch ornamental fish because it made him a good living. This fishing required diving: "When I started diving, my luck doubled" (Gsp_28.02.15) - under water, a new world opened up for him. Soon he knew the underwater rules and where to find the respective species. In contrast to his present isolated and precarious existence at the Transamazônica, which he sought to finance with masonry work, Sérgio called his former existence "a life" (Int_02.03.15). The regular social interactions as well as the identity as a fisherman and his relationship with the river were central aspects that made up this life, as he explained very emotionally: "When I left my house, I stopped at every house of friends, drank a coffee, talked with them and went on. I arrived at the river, waited for the material. Then I went out on the river, the river was there, with open arms, waiting" (Int_02.03.15).

Much more than a profession, fishery was part of Sérgio's personality. This is reflected in his personal relationship to the Xingu, which for him was like "a father, a mother, a friend - and a comrade" (ibid.). One of the foundations of his work was his respect for the river and nature, which is why in his 25 years of fishery the Xingu "never rebelled against me" (ibid.). The river was like a school for him. He learned to catch only as much as he needed and never accused the river, for the river had always fed him.

Sérgio's account shows the importance of the knowledge that the River Xingu taught him. His illiteracy was countered by the education of the Xingu that made him rich in vital knowledge. His perspective regards the Xingu as a non-human but at least equal actor who demands respectful behavior. In this context, he expressed the hope that the Xingu would rebel against Belo Monte and that the power plant would not work (Int_02.03.15). The documentary was a form of mediating and capturing the knowledge and reality of "the fishermen who lived from the river. It is a very beautiful story that I would like to share, both through this film and through my memories" (Int_02.03.15). At the same time, it was a reflection of the break of his personal relationship with fishery and the Xingu. It contained a scene in which he says goodbye to the river "because 
of the respect for the river and the help that he always gave me, [...] to thank him for all that" (Int_02.03.15). Sérgio called himself a "fisherman without a river" (Int_02.03.15), a self-designation that reflected his persistent identity as a fisherman, the experience of dispossession that forbade the further exercise of this profession as well as his inner turmoil, moving between a state of isolation and resignation and the hope for a return to the river.

Sérgio's story provides an impression of the epistemic and ontological foundations of an alternative understanding of property that is inseparable from community life and a personal relationship to the Xingu. Only through this reciprocity is a complete subject existence possible. This understanding of an integrated existence of human and non-human actors thus positions itself in contradiction to a functionalist perspective on river and property, as predominates in the Belo Monte project. Sérgio's separation from the community and from the river means a break in these relationships, a deterritorialization and the consequent loss of the subject existence.

\subsection{MARIA AND NALDO'S “THREATENED PARADISE” AND THE "NEIGHBORHOOD OF GHOSTS"}

Expropriated by the Tucurui Dam, Maria, Naldo and their six children moved to Altamira at the beginning of the 1990s. They bought a plot in the baixão. When Naldo learnt fishing, they constructed another house on an island in the Xingu River, where they started peasant agriculture and where Naldo went out fishing. The peasant agriculture served to provide their own food but the sale of murici, graviola, bananas, manioc and pineapple also generated a considerable income. The river and the island thus met their needs; it was their "supermarket" and their "credit card" (Inf_23.11.14a). However, Maria and Naldo highlighted that this place was much more than this. 60-year-old Maria explained how the river kept her young, it gave her power and refreshed her. When she stayed on her island, all the stress fell away, despite the hard peasant work. During a visit, Maria showed several plants and explained their medicinal and spiritual properties that helped with various physical and mental diseases. The river and every plant had their own story and purpose. In view of the impending dispossession and the already noticeable changes, Maria described the island as her "threatened paradise" (ibid.). Noticing a stronger current in the river, she assumed that the river was already turning "angry" (ibid.). This meant difficulties for them, as they owned two relatively small boats that were not operable in a rough river. 
The statements of Maria and Naldo exemplify both the island's concrete significance for physical survival and its immaterial importance. Naldo explained that Norte Energia disregarded these meanings and provoked "that the fisherman goes stealing and the fisherman's wife eats dirt" (Inf_23.11.14b). Since people had no other choice, there were more crimes in Altamira every day, which, however, were directly linked to the destruction of the islands and the expulsion of the families, which Naldo described as "such a great robbery that no one can comprehend" (ibid.). In contrast to higher compensation at an earlier stage, Norte Energia would now "give only nonsense: 20,000, 10,000, 5,000, 3,000 [reais]" (ibid.). The company could proceed as it wanted and received this supremacy from the government: "The God here is called Norte Energia" (ibid.). For this reason, there were neither judges, nor a mayor, nor deputies, "no one to put in a word for us" (ibid.).

Naldo's words show that the low level of compensation that only considered building materials and crops, combined with the non-recognition of the impact of the dam construction on fishery, was perceived as a lack of respect for the fishing profession and the riverine existence in general. It meant the non-recognition of their own daily and seasonal work and of their performances of having built up this life in the baixão and beiradão without state support. In face of his fruitless struggle for recognition, Naldo felt despair. He visited the consortium repeatedly, sought dialogue and negotiation, but heard nothing but lies from them (GC_14.03.15). Finally, he recognized a system beneath this behavior that was based on economic and political interests and opposed the recognition of his perspective. For this reason, he saw no point in continuing the struggle. This deprivation of social recognition and the concomitant disrespect led Naldo to suffer psychologically and, as he noted, was the reason for his leg disorder that began in the course of the compensation process and worsened at the end of 2014.

Maria and Naldo's narratives unveil an epistemic conflict between the demand for alternative valuation perspectives and criteria, on the one hand, and insistence on the seemingly objective criteria of the price book and the legal ownership structures on the other hand. This indicates the interest structures behind the production of epistemic boundaries. The burning of Naldo and Maria's house, which was mentioned in the introduction, and similar experiences by several riverine families epitomized this non-recognition and disrespect and de facto meant the end of their riverine way of life. Accordingly, the newly constructed "neighborhood of ghosts" reflects the inhabitants' perception of sociocultural death. Because of the low compensation and increased land prices, the neighborhood was located at the urban outskirts, far away from the 
river bank, its ports and the commercial city center. Whereas the autonomous collective resettlement largely preserved their community structures, community life was affected by the precarization of its members. As a neighbor said: "They destroyed them all, they all died" (T_30.09.15). In response to Maria's words that Norte Energia had destroyed her by burning her house in the beiradão, the neighbor said: "See? It's a trauma"(ibid.). During the visit, Naldo related that he had seen a man on television who had been sent to prison for a minor theft. However, the real criminals, he said, were people from the government or from companies like Norte Energia. Nevertheless, they were never prosecuted: "The law is only for the poor pigs, not for those who have money" (ibid.). He fought against these people and for his rights, but got nothing. In light of these injustices, he could no longer fight: "My words are worth nothing" (ibid.).

\section{DISPOSSESSION AND PRECARIZATION: PSYCHOSOCIAL CONSEQUENCES}

The patronizing form of dispossession and resettlement implemented by Norte Energia assigned value to properties according to ownership status and financial values based on vague principles. Furthermore, the assignment of value particularly involved ways of life. It disrespected communitarian structures, connoted life in the baixão as inferior, and non-recognized the dual housing. This was revealed in the decision not to compensate artisanal fishery. In the sense of Butler and Athanasious' (2013, p. 19) “socially assigned disposability", this repeated non-recognition categorized the riverine way of life as worthless. A public lawyer in Altamira called this a "violence of indifference" (Int_22.09.15):

It's worse than going there and attacking the person. You disregard everything she thinks, everything she is, her way of life. I think this is the worst of all acts of violence, don't you? You disregard the existence, the kind of existence of the people (ibid.).

Using epistemic boundaries (whose rigidity Santos (2010) attributes to the dichotomous thinking anchored in dominant Western epistemology) and their influence on the discursive order, alternative forms of knowledge and cognition and the resulting realities and ways of life were marked as invalid and non-existent. Through this assignment of value, the consortium invaded private space, which Arendt (1998, p. 69-71) considers existential for human beings. The deprivation of resources, the loss of neighborhood relations and territorial references and the deprivation of interpretative sovereignty over space 
involved the destruction of people's private space on a material, sociocultural and symbolic level. Bearing in mind the embeddedness of social existence in structures of alterity, this "becoming dispossessed" (BUTLER; ATHANASIOU, 2013 , p. 5) meant the withdrawal of the validity of people's way of life and reality. It was symbolized by the burnt houses and materialized in the specific form of physical expropriation, low compensation and dispersed resettlement. As the riverine people had no direct links to the consortium's authorities, they were not accepted as negotiating partners and, in case of non-compliance, were confronted with repression (cf. CHAUI, 2012). The production of these people as precarious, that is, as lives "[that] do not qualify as recognizable, readable, or grievable" (BUTLER, 2009, p. xii-xiii) confirms dispossession as an instrument of control and appropriation which expels certain groups to their "proper place" (BUTLER; ATHANASIOU, 2013, p. 18). In the case of the riverine people, the peripheral location of these places is emblematic for their social marginalization. Deprived of essential resources and the way of life associated with them, this process put them in a state "of perennial occupation as nonbeing and non-having" (ibid., p. 19) - a state reflected in their statements about the neighborhood of ghosts. This deprivation of social recognition violated the dignity and social integrity of many affected riverine people and manifested in traumas, depression, states of exhaustion and in the accumulation of physical, in particular cardiovascular, diseases (T_22.11.14, T_30.09.15; see also KATZ; OLIVEIRA, 2016). Statements like "I can't fight anymore" or "my words are worth nothing" point to the psychosocial consequences that impaired the ability of the affected to act in concert and produce the power that is crucial for the production of spaces of appearance, that is, a public in which they can appear and be heard and seen.

According to interviewees (cf. Int_18.03.15), the destruction of their private realm involved a process of deterritorialization. Territoriality - that is, the ability to exercise control and influence over a territory (HAESBAERT, 2004, p. 86-87) - was enabled by mutual recognition within the community. This recognition by the group "gives [...an individual] the imaginary and symbolic prerequisite to be able to position himself [sic!], to move and to act over the territory" (KATZ; OLIVEIRA, 2016, p. 234).'Territoriality as agency constituted the particular existence as riverine people and signified a certain "being-in-theworld" (ibid., p. 233). Being a fisher in this particular section of the Xingu thus meant more than a profession, namely a specific form of occupying a territory and acting over it. Deterritorialization is the processual loss of these relations. 
Sérgio's self-designation as a "fisherman without a river" underlines his existence as "a subject without the possibility to regulate its belonging" (ibid.). This points to the untenability of this condition, because - just like in the neighborhood of ghosts - a life without the river seems impossible. Thus, self-identity is so much affected by this loss that the appropriation of the new locality and the production of new territorialities appear inconceivable. As expressions like "our river" (PO_29.09.15) or "the Xingu is our life" (Int_26.02.15) reflect, "living with and relating to the river is what keeps the entire system of identifications of this community functioning" (KATZ; OLIVEIRA, 2016, p. 233). The affected riverine people were transformed from complete subjects and citizens into ghosts, who, despite the construction of their new neighborhood, consider their lives to be over and do not see any perspective in their new existence. This is proven by statements like "they destroyed them all, they all died" (Inf_30.09.15) or "we are like birds whose wings have been cut off" (Inf_19.09.15). Following Leroy (2011), this production of people disconnected from their territory - the desconectados - is a common consequence of projects of spatial valorization and its resulting "brutal process of spatial domination through capital" (ibid., p. 4; cf. CORRÊEA, 2016). Similar to Sérgio's assessment about the invisibilization of artisanal fishery, the capitalist agents often render invisible the subaltern people who formerly moved within the territory. As Santos (2014, p. 171-172) argues, "what does not exist is in fact actively produced as non-existent, that is, as a noncredible alternative to what exists."

People affected by dispossession are not mute victims. Processes of precarization and the production of invisibility can powerfully impede their political agency. However, if dispossessed people succeed in organizing themselves and raising political awareness - perhaps with the help of experienced political activists - they might be able to confront their invisibilization with performative acts of visibility and their inherent demand for recognition. Following Butler and Athanasiou (2013), with reference to Arendt (1998), the power of dispossession and its underlying symbolic order can be challenged when precarious people come together, act in concert and instrumentalize the repressive conditions and the forces of dispossession through direct confrontation. An appropriation of these conditions can reinterpret their vulnerable exposure into a: "“[w] e are still here', meaning: $[\ldots]$ 'we have not become the glaring absence that structures your public life"' (ibid., p. 196). Such a disclosure of the limits of intelligibility can irritate, challenge the norms and, eventually, initiate a shift in recognition structures. In the case of the riverine people in the Xingu region, their solicitation of the 
regional Xingu Vivo movement and Altamira's Federal Public Prosecution (MPF) led to an on-site study. Organized by the MPF and accompanied by researchers and important public institutions - including the licenser Ibama -, it unveiled the precarious situation of the riverine people and resulted in a project of resettlement to the shores of the future reservoir (cf. MPF, 2015). In a series of public audiences, meetings and workshops starting in September 2015 (PO_29.09.15), the riverine people used this project as a platform to demonstrate their realities, epistemologies and ontologies, their being riverine and their perspective on Belo Monte and the dispossession process. However, the discursive dominance of Norte Energia manifested itself in the consortium's control of the project, the prevailing non-recognition of the riverines' way of life, and its interest-based autonomous selection of resettlement areas and people to resettle (cf. GRUPO DE ACOMPANHAMENTO INTERINSTITUCIONAL, 2017). In light of this prevailing dominance, the riverine people tried to appropriate the project. They joined with NGOs and academics, undertook several on-site inspections and workshops, and finally autonomously designed resettlement areas according to their needs (cf. CUNHA; MAGALHÃES, 2016). A Riverine Council was founded as a political body. The council initiated a two-month process of social recognition in which the participating riverine people discussed and defined "being riverine" and compiled a list of riverine people to resettle (GRUPO DE ACOMPANHAMENTO INTERINSTITUCIONAL, 2017). This process and the acceptance of both the Riverine Council and the list by the licensor Ibama represented an important process of recognition and self-affirmation, as several riverine people and social movement activists confirmed (cf. Int_04.12.17, Int_19.12.17). Furthermore, the riverine people succeeded in introducing alternative meaning structures into the mainstream discourse concerning ways of life, concepts of property and livability. However, at the moment of writing this paper, this symbolic recognition has not materialized in an actual physical resettlement. Once again, Norte Energia has assumed a dominating and authoritarian role by delaying the process and making vague concessions, leading to several riverine people resigning and dissociating themselves from the Riverine Council (cf. Inf_14.07.19, PO_27.09.18).

\section{CONCLUSIONS}

This paper intends to contribute to a conceptualization of dispossession that enables a deeper analytical knowledge of the mechanisms and multi-level 
effects of the same. To this end, I have introduced Butler and Athanasiou's (2013) dual concept of dispossession that takes into account a subject's embeddedness in structures of alterity and the symbolic order (being dispossessed). The dependence that derives from the need for social recognition is decisive for the psychosocial impact of experiences of the deprivation of recognition, rights and the validity of ways of life and realities (becoming dispossessed). Regarding the example of Belo Monte, the implementation of the large-scale project involved an authoritarian and paternalistic invasion into the private sphere of the affected people. The example of the riverine people demonstrates a concomitant non-recognition of their way of life and reality and the consequent destruction of their private realm that had been built on complex community structures of social and economic exchange, enabled through mutual recognition, the dual housing model and the resulting territorialities. The narratives of Naldo, Sérgio and Maria provide an insight into the dimensions of individual experiences of dispossession. They confirm what Butler and Athanasious (2013) and Butler (2009, 2011, 2015) call a process of precarization. First, they suffered material consequences from their displacement and the disruption of their way of life and livelihood. These consequences became definite with the unfavorable conditions of their "proper places" and caused a complex process of deterritorialization. Second, this disruption was framed by the non-recognition of everything that had made up their life. This comprised the ontological and epistemological dimension as it affected their concept of the network of human-nature relationships and the function of each element, including their own role within this network, their inherent understanding of property, and related knowledge. The severe psychosocial consequences resulting from the experiences of dispossession, deterritorialization and non-recognition are revealed, for instance, in the way in which Naldo suffered from loneliness and from the disruption of his relationships within the community and with the river, as well as by the narrative of the "neighborhood of ghosts".

Regarding development projects that foresee the reproduction of destructured ways of life after resettlement, these findings indicate the importance of recognizing alternative ways of life and realities and inherent concepts of, for instance, property and human-nature relations. This requires, first, careful qualitative and participative research in order to detect meaning structures and, second, the acceptance of coexisting and, possibly, contradictory concepts with an equal right to exist. Furthermore, it requires equal participation of affected people who need to be organized within autonomous structures like the Riverine Council. The short insight into the political struggle for recognition of the riverine 
people indicates, on the one hand, the importance of self-organization but also, on the other hand, the prevailing domination of the consortium and the discrepancy between the assignment of recognition and its materialization. The Belo Monte project confirms Butler and Athanasious' (2013) designation of dispossession as an instrument of control and appropriation. The empirical examples show the power-political aspect of the inherent territorial claim that is backed by complex economic and political interests. This contradicts the interests of affected people in maintaining their integrity, dignity and territorialities. Therefore, there are justifiable doubts about whether the aforementioned requirements are likely to be fulfilled within a capitalist development project. It seems more likely that an assignment of decision-making power will rather be used as a pretext to achieve capitalist goals.

\section{REFERENCES}

ARENDT, A. The human condition. Chicago, London: The University of Chicago Press, 1998. 370 p.

ARENDT, A. Between past and future: eight exercises in political thought. New York: Penguin Books, 2006. 320 p.

BORRAS, S. M.; FRANCO, J. C. Global land grabbing and political reactions 'from below'.Third World Quarterly, [S. l.], v. 34, n. 9, p. 1723-1747, 2013.

BUTLER, J. Performativity, precarity and sexual politics. AIBR: Revista de Antropología Iberoamericana, [S. l.], v. 4, n. 3, p. i-xiii, 2009.

BUTLER, J. Bodies in alliance and the politics of the street. EIPCP, Venice, 7. Sept. 2011. Available at: https://pdfs.semanticscholar.org/9cf5/3d72261800bc7 ac2f7353270a8f59287a9be.pdf. Acesso em: 08 Aug. 2019.

BUTLER, J. Notes towards a performative theory of assembly. Cambridge: Harvard University Press, 2015. 248 p.

BUTLER, J.; ATHANASIOU, A. Dispossession: the performative in the political. Cambridge: Polity Press, 2013. 240 p.

CERNEA, M. M. The risks and reconstruction model for resettling displaced populations. World Development, [S. l.], v. 25, n. 10, p. 1569-1587, 1997.

CERNEA, M. M.; GUGGENHEIM, S. E. Anthropological approaches to resettlement: policy, practice, and theory. Boulder: Westview Press, 1993. 406 p. 
CHAUI, M. Democracia e sociedade autoritária. Comunicação \& Informação, Goiânia, v. 15, n. 2, p. 149-161, 2012.

CORRÊA, S. R. M. Neodesenvolvimentismo e conflitos sociais: o caso da Hidrelétrica de Belo Monte. Novos Cadernos NAEA, Belém, v. 19, n. 3, p. 233-254, 2016.

CUNHA, M. C.; MAGALHÃES, S. Estudo sobre o deslocamento compulsório de ribeirinhos do rio Xingu provocado pela construção de Belo Monte: avaliação e propostas. Altamira: SBPC, 2016. 450 p.

ELETROBRÁS. Complexo Hidrelétrico Belo Monte: Estudo de Impacto Ambiental - E I A. Versão preliminar. Brasília, DF: Eletrobrás, 2009.

ESCOBAR, A. Imagining a post-development era? Critical thought, development and social movements. Social Text, New York, v. 31/32, p. 20-56, 1992.

GRUPO DE ACOMPANHAMENTO INTERINSTITUCIONAL. Conselho ribeirinho do reservatório da UHE Belo Monte: relatório do processo de reconhecimento social. Altamira: MPF: UFPA: Unicamp: ISA: Mov. Xingu Vivo Para Sempre, 2017.

HAESBAERT, R. O mito da desterritorialização: do "fim dos territórios" à multiterritorialidade. Rio de Janeiro: Bertrand Brasil, 2004. 395 p.

HAESBAERT, R. Da desterritorializacao à multiterritorialidade. In: ENCONTRO DE GEÓGRAFOS DA AMÉRICA LATINA, 10., 2005, São Paulo. Anais [...]. São Paulo: USP, 2005. p. 6774-6792.

HALL, D. Primitive accumulation, accumulation by dispossession and the global LandGrab. Third World Quarterly, [S. l.], v. 34, n. 9, p. 1582-1604, 2013.

HARVEY, D. The new imperialism. Oxford, New York: Oxford University Press, 2003. 261 p.

HEGEL, G. W. F. Phänomenologie des Geistes. Stuttgart: Reclam, [1807] 1987. 597p.

HEGEL, G. W. F. Grundlinien der Philosophie des Rechts. Special edition based on the "Gesammelte Werke", Hamburg: Felix Meiner, [1820] 2015. 3274 p. HOWITT, R.; STEVENS, S. Cross-cultural research: ethics, methods, and relationships. In: HAY, I. (ed.). Qualitative research methods in human geography. South Melbourne, New York: Oxford University Press, 2005. p. 30-50. ISA. De olho em Belo Monte: 2013, no pico da contradição. São Paulo: ISA, 2013. 
KATZ,I.;OLIVEIRA,L.Impactos em Saúde. In:CUNHA, M. C.; MAGALHAES, S. (ed.). Estudo sobre o deslocamento compulsório de ribeirinhos do rio Xingu provocado pela construção de Belo Monte. Altamira: SBPC, 2016. p. 205-240.

LEROY, J-P. Justiça ambiental. Grupo de Estudos em Temáticas Ambientais, Belo Horizonte, fev. 2011. Disponível em: https://conflitosambientaismg. lcc.ufmg.br/wp-content/uploads/2014/04/TAMC-LEROY_Jean-Pierre_-_ Justi\%C3\%A7a_Ambiental.pdf. Acesso em: 8 ago. 2019.

LEVIEN, M. The land question: special economic zones and the political economy of dispossession in India. Journal of Peasant Studies, [S. l.], v. 39, n. 3-4, p. 933-969, 2012.

MAB. As violações de direitos na remoção dos atingidos por Belo Monte na área urbana de Altamira. In: ISA. Dossiê Belo Monte: não há condições para a Licença de Operação. São Paulo: ISA, 2015. p. 107-113.

MEISSNER, H. Butler. Stuttgart: Reclam, 2012. 130 p.

MPF. Relatório de Inspeção Interinstitucional: áreas ribeirinhas atingidas pelo processo de remoção compulsória da UHE Belo Monte. Altamira: MPF, 2015. 125 p.

NORTE ENERGIA. Projeto básico ambiental da Usina Hidrelétrica Belo Monte: planos, programas e projetos. Altamira: Norte Energia, 2010.

NORTE ENERGIA. Avaliação sobre as percepções dos pescadores da Volta Grande do Xingu sobre possíveis impactos localizados decorrentes da UHE Belo Monte: relatório técnico. Altamira/PA. Altamira: Norte Energia, 2015. $51 \mathrm{p}$.

NORTE ENERGIA. UHE Belo Monte, a maior hidrelétrica $100 \%$ brasileira. Norte Energia, Altamira, 2019. Available at: norteenergiasa.com.br. Access in: 5 Aug. 2019.

OLIVER-SMITH, A. Displacement, resistance and the critique of development: from the grass roots to the global. London: Oxford, 2001.125 p. OLIVER-SMITH, A. (Ed.). Development \& dispossession: The crisis of forced displacementand resettlement. Santa Fe: School for Advanced Research Press, 2009. 330p.

SAID, E. W. The politics of dispossession: the struggle for Palestinian selfdetermination, 1969-1994. New York: Vintage, 1995. 450 p. 
SANTOS, B. S. Para além do pensamento abissal: das linhas globais a uma ecologia de saberes. In: SANTOS, B. S.; MENESES, M. P. (org.). Epistemologias do Sul. Coimbra: Editora Almedina, 2010. p. 23-72.

SANTOS, B. S. Epistemologies of the South: justice against epistemicide. London, New York: Routledge, 2014. 240 p.

SIFFERT, N; CARDOSO, M; MAGALHÃES, W. A.; LASTRES, H. M. M. Um olhar territorial para o desenvolvimento: Amazônia. Rio de Janeiro: BNDES, 2014. 413 p.

WEISSERMEL, S. Consequências das condicionantes de remoção para os atingidos no âmbito do Reassentamento Urbano Coletivo. In: ISA. Dossiê Belo Monte: não há condições para a Licença de Operação. São Paulo: ISA, 2015. p. 136-139. 